\title{
IDENTIFIKASI ZONA SHALE PROSPEKTIF BERDASARKAN DATA WELL-LOG DI CEKUNGAN SUMATRA SELATAN
}

\author{
Jamaluddin $^{1 *}$, Maria ${ }^{2}$ \\ ${ }^{1}$ Geological Engineering, School of Geosciences, China University of Petroleum (East China), Qingdao, China. \\ ${ }^{2}$ Laboratorium Geofisika Padat, Departemen Geofisika, FMIPA Universitas Hasanuddin \\ *Penulis koresponden. Alamat email: jamaljamaluddin1994@gmail.com
}

\begin{abstract}
Abstrak
Kebutuhan bakan bakar fosil terutama minyak dan gas bumi terus meningkat, akan tetapi jumlah cadangan bahan bakar fosil semakin menurun sehingga terdapat ketidakseimbangan antara kebutuhan dan persediaan. Salah satu alternatif ketahanan energi nasional yaitu beralih dari sumber daya konvensional ke non-konvensional seperti shale gas dan shale oil. Penelitian tersebut bertujuan untuk mengidentifikasi zona serpih prospektif pada sumur JML-1 berdasarkan data rekaman sumur. Penentuan zona shale prospektif diidentifikasi menggunakan pendekatan metode $\Delta$ LogR (Metode Passey's) dengan melakukan overlay antara log sonik dan log resistivitas. Berdasarkan pendekatan metode Passey, Sumur JML-1 teridentifikasi 4 (empat) zona shale prospektif yang memiliki tingkat kekayaan organik (TOC) $0.72-6.12 \%$ wt. Cekungan Sumatra Selatan memiliki potensi cadangan shale yang cukup besar sehingga dibutuhkan integrasi beberapa metode untuk mengevaluasi lebih dalam.
\end{abstract}

Kata Kunci: Cekungan Sumatra Selatan, Non-konvensional, Prospektif, Shale, Well log.

\begin{abstract}
The need for fossil fuels, especially oil and gas continues to increase, but the amount of fossil fuel reserves is decreasing so there is an imbalance between demand and supply. One alternative to national energy security is switching from conventional to unconventional resources such as shale gas and shale oil. The study aimed to identity prospective shale zones in JML-1 well based on well log data. Prospective shale zone determination was identified using the $\Delta \operatorname{LogR}$ method (Passey method) to approach by overlaying sonic logs and resistivity logs. Based on the Passey's method, JML-1 identified 4 (four) prospective shale zones that had organic rich (TOC) 0.72-6.12 wt. \%. The South Sumatra Basin has a large potential reserves of shale, so it requires the integration of several method's to evaluate deeper.
\end{abstract}

Keywords : South Sumatra Basin, Unconventional, Prospective, Shale, Well Log.

\section{Pendahuluan}

Kebutuhan bahan bakar fosil terutama minyak dan gas bumi semakin meningkat seiring perkembangan waktu. Akan tetapi peningkatan kebutuhan energi tidak seiring dengan jumlah persediaan bahan bakar sehingga terjadi ketidakseimbangan antara kebutuhan dan persediaan. Oleh karena itu, diperlukan adanya alternatif energi baru yang ramah lingkungan dan murah sebagai solusi atas kebutuhan energi nasional seperti shale gas dan shale oil.

Shale merupakan batuan sedimen yang yang mempunyai ukuran butir halus yang 
didominasi oleh susunan mineral lempung dan berstruktur laminasi. Formasi Shale terendapkan di lingkungan yang memiliki low energy seperti tidal flats dan deepwater basin. Shale dapat mengandung unsur material organik yang melimpah, yang disebut organic rich shale sehingga menghasilkan hydrocarbon shale. Selama proses pengendapan, sedimen halus terakumulasi oleh material organik seperti algae, tumbuhan, dan fosil hewan laut (Davis, 1992).

Berdasarkan data Badan Geologi Indonesia (2011), total potensi shale gas di Indonesia adalah sekitar 574,07 TCF dan shale oil 11,24 juta ton. Dari data tersebut, beberapa cekungan di Indonesia sangat berpotensi untuk memproduksi shale gas dan shale oil seperti cekungan Sumatra Selatan. Penelitian ini bertujuan untuk menentukan lapisan zona target shale yang diinterpretasikan sebagai zona shale yang prospektif berdasarkan data rekaman sumur (well log).

\section{Geologi Regional dan Stratigrafi Cekungan Sumatra Selatan}

Cekungan Sumatra Selatan terbentuk melalui 4 (empat) periode tektonik, yaitu tektonik Mesozoikum Tengah, Akhir Kapur-Awal Tersier, Intra Miosen, dan Plio-Pleistosen (Pulonggono, 1992) (Gambar 1).

Tektonik periode Mesozoikum Tengah merupakan fase kompresi yang membentuk pola patahan $E S E-W N W$, diantaranya Patahan Lematang dan pola patahan berarah $N-S$, diantaranya patahan yang membentuk Benakat Gulley. Aktivitas tektonik ini menyebabkan sedimensedimen berumur Paleozoikum mengalami perlipatan, metamorfosa, dan diintrusi oleh batholit granit, kemudian menjadi batuan dasar sub-cekungan Palembang Selatan.

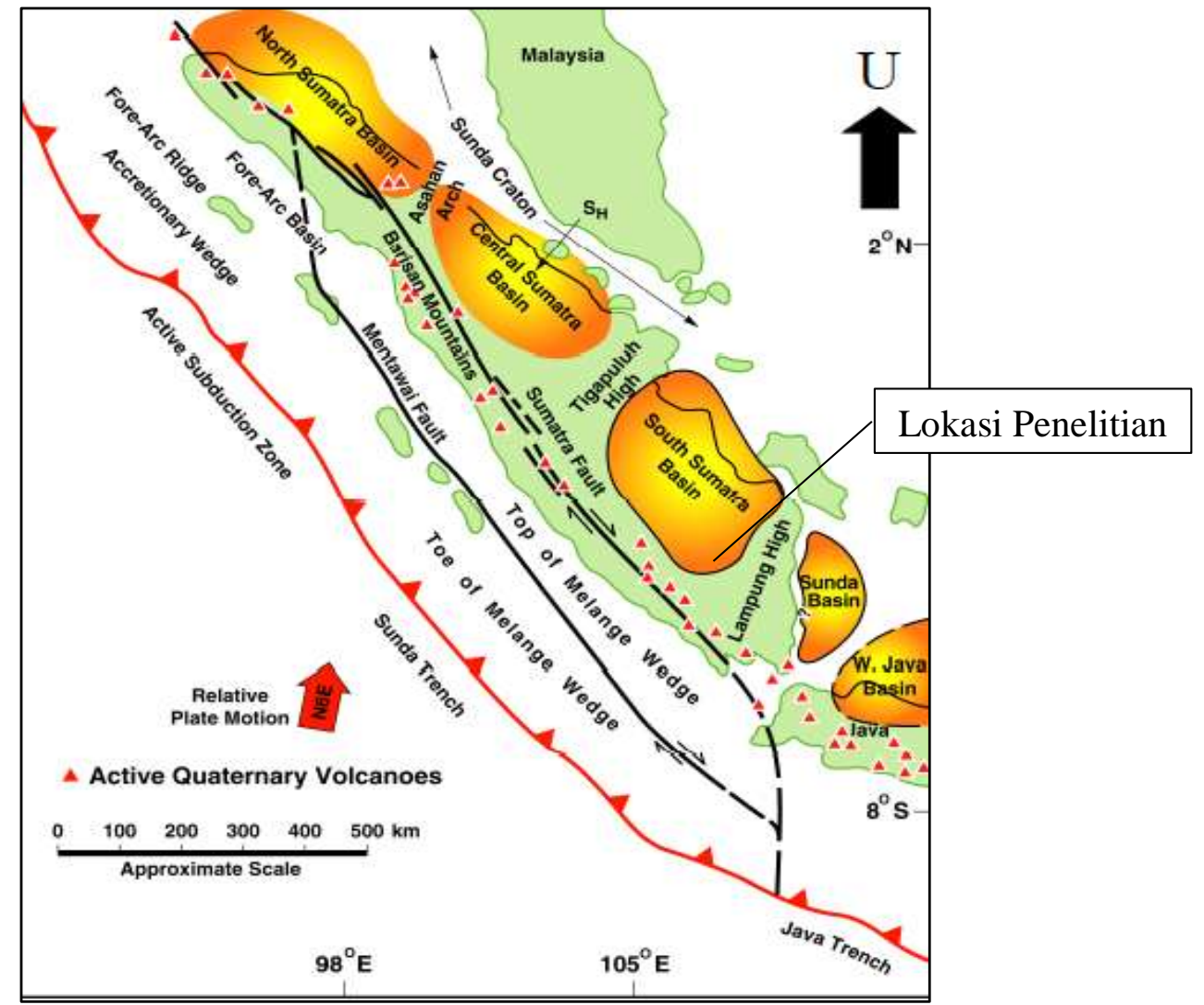

Gambar 1. Tektonik Cekungan Sumatra Selatan (Heidrick \& Aulia, 1993) 
Tektonik Akhir Kapur-Awal Tersier merupakan fase ekstensi yang menyebabkan terbentuknya sesar mendatar kekanan (dextral) Semangko. Akibat pergerakan sesar tersebut terbentuk horst dan graben berarah $N-S$ dan $N N E-S S W$, mengikuti pola rekahan yang terbentuk sebelumnya. Pada periode ini diendapkan sedimen Formasi Lahat (LAF) di lingkungan fluvial-lacustrine yang sangat dipengaruhi oleh aktivitas vulkanik pada Kala Oligosen. Berikutnya secara tidak selaras di atas LAF diendapkan Formasi Talang Akar (TAF) di lingkungan fluvial deltaic. Selaras di atas TAF diendapkan Formasi Baturaja (BRF) di lingkungan litoral neritik dangkal pada Kala Miosen Bawah. Selaras di atas BRF diendapkan Formasi Gumai (GUF). Pada fase ini terjadi proses pengendapan seri transgresi dan mencapai puncak transgresi pada Kala
Miosen Tengah bagian bawah yaitu pada saat Formasi Gumai diendapkan di lingkungan neritik dalam.

Tektonik Intra Miosen merupakan fase kompresi yang menyebabkan terangkatnya dasar cekungan dan awal pembentukan Pegunungan Bukit Barisan sehingga seluruh cekungan Sumatra Selatan mengalami regresi. Fase ini sering disebut sebagai fase inversi karena patahan-patahan berpola $E S E-W N W$ yang sebelumnya merupakan patahan normal berubah menjadi patahan naik. Pada periode ini diendapkan sedimen Formasi Air Benakat (ABF) di lingkungan litoral-neritik dangkal pada Kala Miosen Tengah dan Formasi Muara Enim (MEF) pada lingkungan shallow marine-deltaic pada Kala Miosen Atas dalam fase regresif.

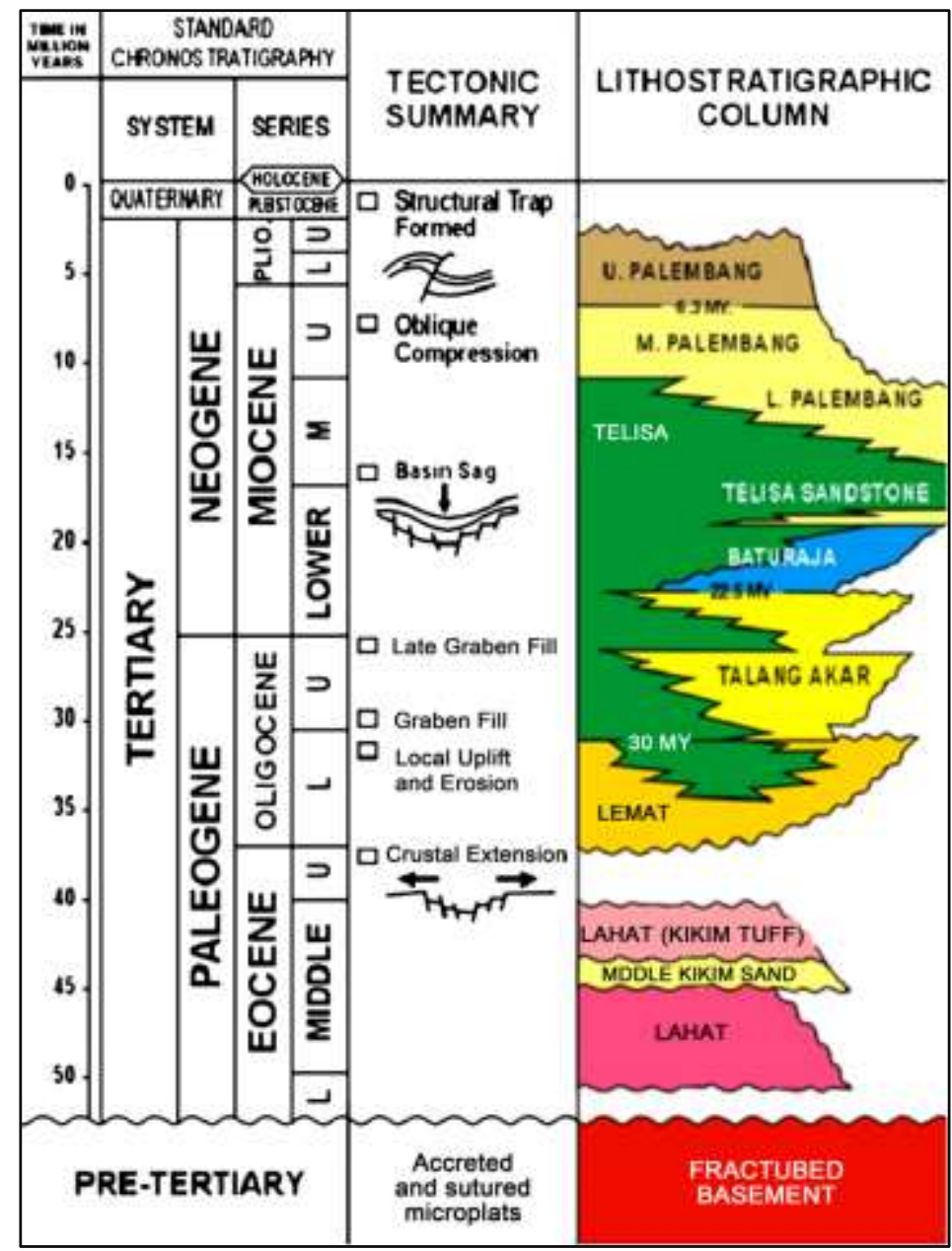

Gambar 2. Stratigrafi Regional Cekungan Sumatra Selatan (De Coaster, 1974). 
Berdasarkan penelitian terdahulu, urutan sedimen Tersier di Cekungan Sumatra Selatan dibagi menjadi dua tahap pengendapan, yaitu genang laut dan tahap susut laut. Sedimen yang terbentuk pada tahap genang laut disebut kelompok Telisa, dari umur Eosen awal hingga Miosen tengah terdiri atas Formasi Lahat (LAF), Formasi Talang Akar (TAF), Formasi Baturaja (BRF) dan Formasi Gumai (GUF), sedangkan yang terbentuk pada tahap susut laut disebut kelompok Palembang, dari umur Miosen tengah sampai Pliosen, terdiri atas Formasi Air Benakat (ABF), Formasi Muara Enim (MEF), dan Formasi Kasai (KAF) (gambar 2) (de Coster, 1974).

\section{Petroleum System Cekungan Sumatera Selatan}

Pada sistem petroleum ini dijelaskan mengenai batuan induk, kematangan batuan, pola migrasi yang terjadi, reservoir hidrokarbon, tipe geometri dan kualitas dan jenis perangkap yang ada (gambar 3).

\section{Batuan Induk (Source Rock)}

Batuan induk di daerah ini adalah shale Formasi Talang Akar, berpotensi bagus dan matang. Analisa geokimia sampel batuan menunjukkan $\mathrm{TOC}=0,70-11,22 \%, \mathrm{~S} 1+\mathrm{S} 2$ $=1,58-38,90$, Tmaks $=427^{\circ} \mathrm{C}-444^{\circ} \mathrm{C}$, $\mathrm{Ro}=0,50-0,82, \mathrm{HI}=182-313$. Tipe kerogen campuran tipe II/III sehingga dapat menghasilkan minyak dan gas prone.

\section{Migrasi (Migration)}

Berdasarkan oil to source correlation migrasi hidrokarbon pada daerah tersebut merupakan tipe near distance migration dari batuan induk mengisi reservoir di sekitarnya. Migrasi dan perangkap diperkirakan terjadi saat terbentuknya hidrokarbon pada Miosen Akhir sampai sekarang.

\section{Batuan Waduk (Reservoir)}

Reservoir yang berpotensi menghasilkan hidrokarbon adalah batupasir Formasi Talang Akar (TAF) Gritsand Member (GRM) dan Transitional Member (TRM). Batupasir Formasi Talang Akar yang diendapkan dalam sistem tidal dominated delta dengan sumber sedimen berasal dari barat laut. Formasi Talang Akar bagian bawah secara umum diendapkan di daerah delta plain sebagai endapan point bar dengan parameter reservoir $\varnothing=7-32 \%$, Rt $=2-60 \Omega, \mathrm{Sw}=20-86 \%$, Netpay $=1-21 \mathrm{~m}$ dan $\mathrm{K}=100-1016 \mathrm{md}$, sedangkan bagian atas secara umum diendapkan di daerah delta front sebagai endapan tidal bar dengan parameter reservoir $\varnothing=8-30 \%$, Rt $=2-63 \Omega, \mathrm{Sw}=21-94 \%$, netpay $=1-8 \mathrm{~km}$ dan $\mathrm{K}=0.1-1000 \mathrm{md}$.

\section{Batuan Penyekat (Seal)}

Batuan yang berperan sebagai batuan penyekat bersifat regional, dijumpai sebagai shale yang tebal dari Formasi Telisa / Gumai (GUF) dan dari shale yang terdapat pada intra-formasi di dalam tiaptiap zona batupasir pada masing-masing formasi. Shale ini meskipun ketebalannya relatif tipis, namun terbukti dapat berfungsi secara baik sebagai batuan penyekat (seal) bagi migrasi/ akumulasi minyak dan gas untuk lapisan-lapisan reservoir yang ada di bawahnya.

\section{Perangkap (Trap)}

Hidrokarbon ditemukan lapangan-lapangan minyak dan gas baru, yang umumnya juga ditemukan sebagai kombinasi perangkap struktur dan stratigrafi (isolated channel). 


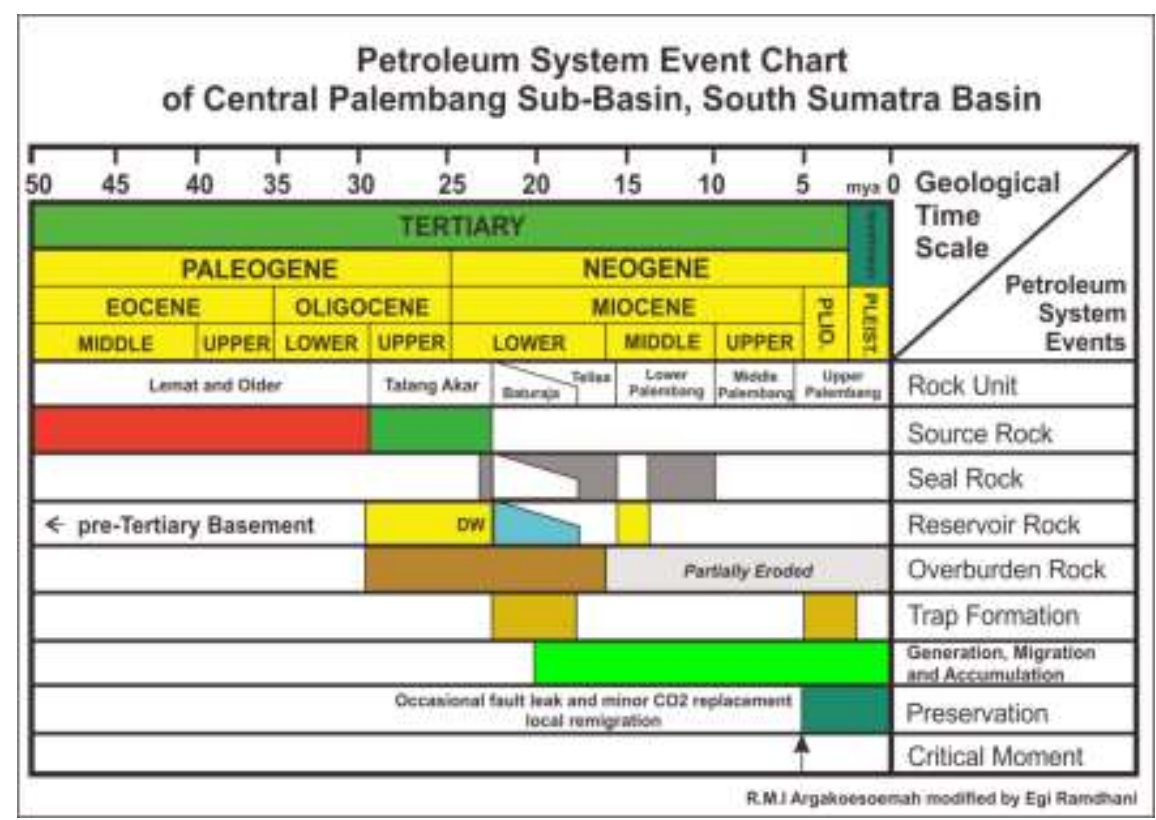

Gambar 3. Petroleum System Event Chart Cekungan Sumatra Selatan (Argakoesoemah dan Kamal, 2004).

\section{Metode Penelitian}

Ada pun data-data yang digunakan dalam penelitian tersebut yaitu data core dan data sumur. Data sumur yang tersedia umumnya data gamma ray, resistivitas, neutron, densitas, dan sonik. Respon log dari lapisan shale yang mengandung hidrokarbon yaitu:

- nilai gamma ray yang tinggi,

- nilai resistivitas yang tinggi,

- nilai densitas yang rendah,

- nilai sonik yang tinggi.

Metode Passey $(\Delta \log R)$ adalah metode yang digunakan untuk menentukan zona shale prospektif berdasarkan hasil plot silang antara log resistivitas dan transit time sonic yang apabila terjadi crossover antara $\log$ resistivitas dan log transit time sonic, maka zona tersebut adalah zona potensial untuk shale play yang kaya akan kandungan organik (gambar 4). Nilai resistivitas akan meningkat bersamaan dengan kurva gamma ray karena dianggap shale pada zona tersebut sudah matang dan mengandung hidrokarbon.

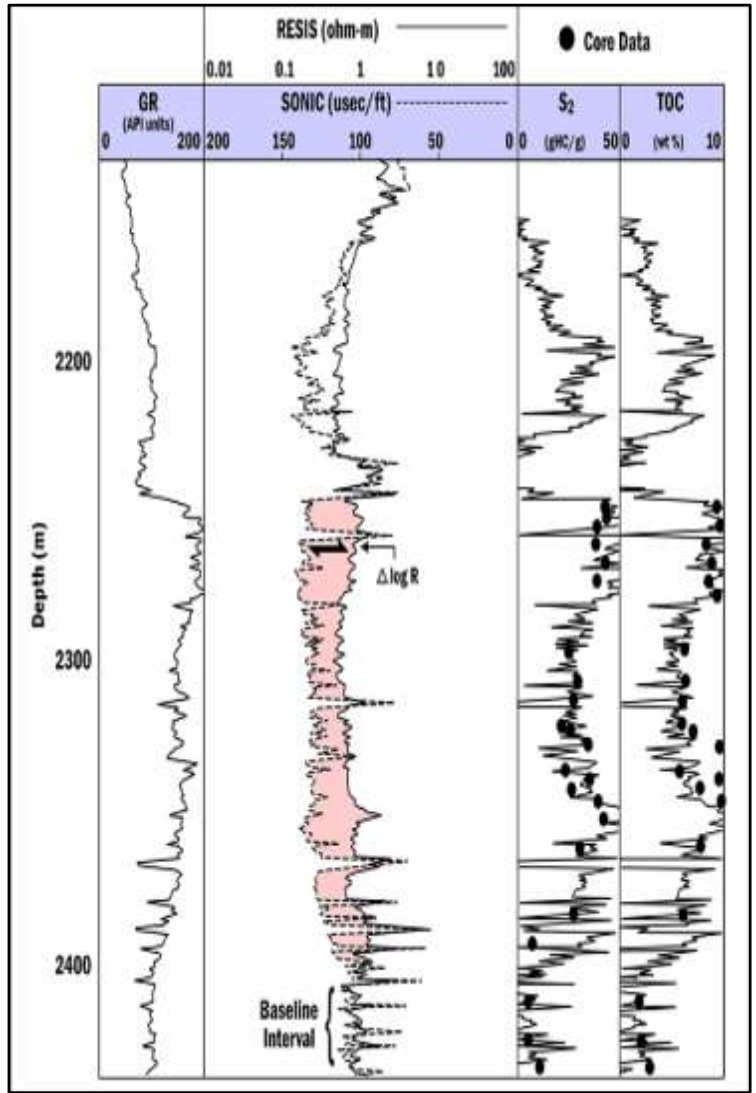

Gambar 4. Plot silang antara log resistivitas dan log sonik untuk memodelkan log TOC (Passey, 1990). 


\section{Hasil dan Pembahasan}

Berdasarkan pendekatan metode Passey.,et al. (1990), Sumur JML-1 teridentifikasi 4 (empat) zona target shale (shale play) berdasarkan hasil crossplot antara log resistivitas dan log transit time sonic (gambar 5). Interval crossover semakin lebar disebabkan karena shale pada zona yang teridentifikasi sebagai shale play memiliki kandungan kerogen yang semakin tinggi dan sudah matang.
Tingginya nilai pembacaan log gamma ray yang disebabkan oleh kandungan radioaktif Uranium (U) secara tidak langsung dapat diasosiasikan dengan material organik yang terkandung di dalam batuan tersebut. Sedangkan tingginya pembacaan gamma ray yang disebabkan oleh radioaktif Thorium (Th) dan Kalium (K) dapat diasosiasikan dengan kandungan mineral mika dan mineral clay (Aly et al.,1990).

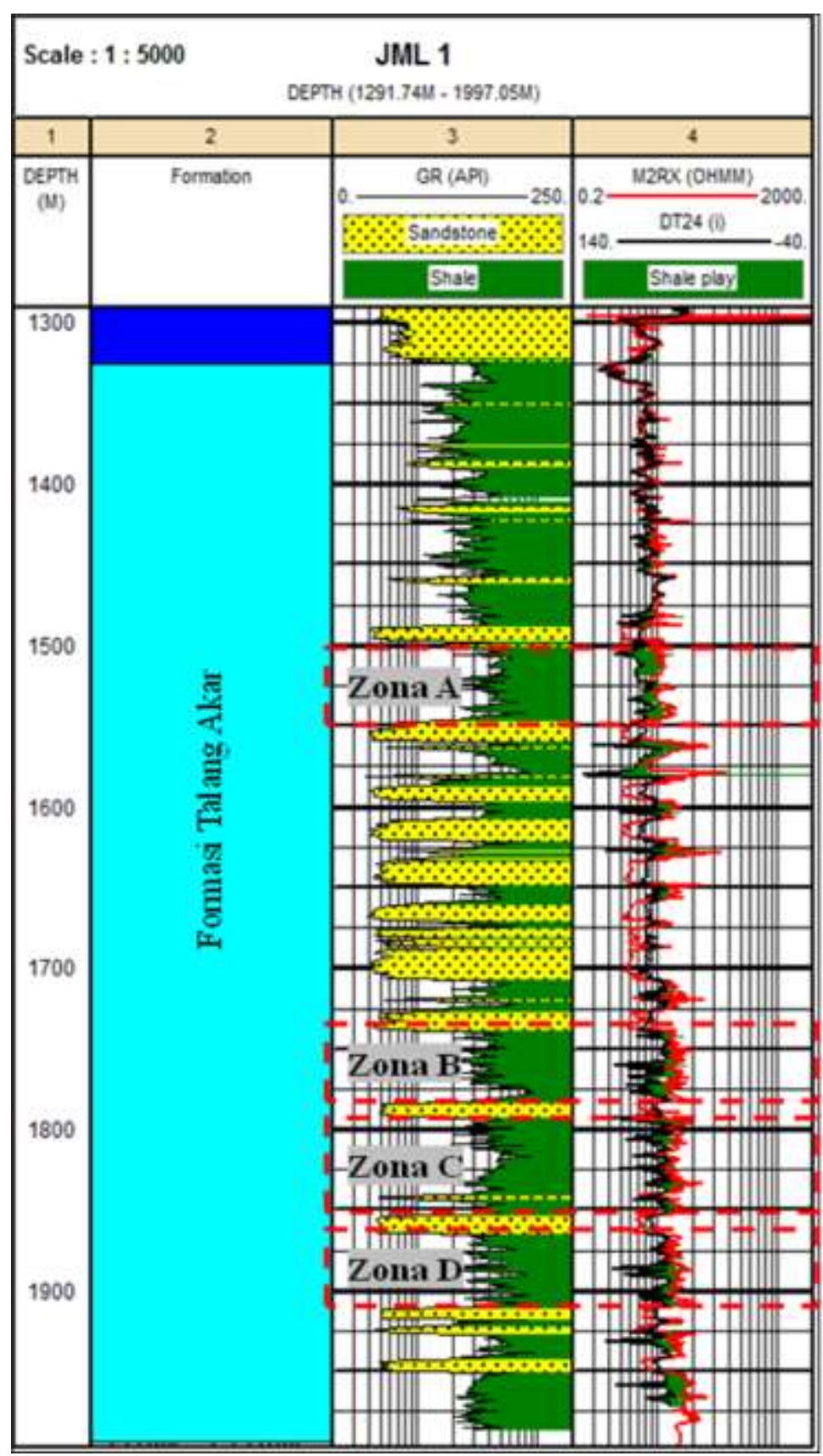

Gambar 5. Plot silang antara log sonik dan log resistivitas untuk mengidentifikasi

¡ 2019 Dept. of Geophysics Hasanuddin University 
Tabel 1. Zona interest berdasarkan hasil plot silang antara log sonik dan log resistivitas.

\begin{tabular}{ccc}
\hline Zona & $\begin{array}{c}\text { Kedalaman } \\
(\mathbf{m D})\end{array}$ & $\begin{array}{c}\text { Ketebalan } \\
(\mathbf{m})\end{array}$ \\
\hline $\mathrm{A}$ & $1497-1546$ & 49 \\
\hline $\mathrm{B}$ & $1738-1784$ & 46 \\
\hline $\mathrm{C}$ & $1792-1852$ & 60 \\
\hline $\mathrm{D}$ & $1863-1910$ & 47 \\
\hline
\end{tabular}

Penentuan zona dominan shale dan dominan batupasir dilakukan plot silang antara nilai porositas densitas dan porositas neutron kemudian dibuat garis regresi yang bertujuan untuk memisahkan antara zona yang didominasi lapisan sandstone dengan zona yang didominasi shale.

Zona yang berada di bawah garis regresi linear diidentifikasi sebagai zona yang dominan shale dan zona dominan sandstone berada di atas garis regresi. Hal tersebut dikarenakan batupasir/ sandstone memiliki porositas lebih tinggi dibandingkan dengan shale (gambar 6). Metode tersebut telah digunakan oleh Katahara (2008) dalam memisahkan lapisan yang didominasi pasir dengan lapisan yang didominasi shale pada formasi yang tersusun oleh campuran pasir dan shale (shaly sand). Litologi yang mengandung konten organik dan atau hidrokarbon akan memiliki densitas yang lebih kecil dari lapisan tanpa fluida. Definisi tersebut berlaku untuk lapisan shale yang mengandung konten organik dan atau fluida.

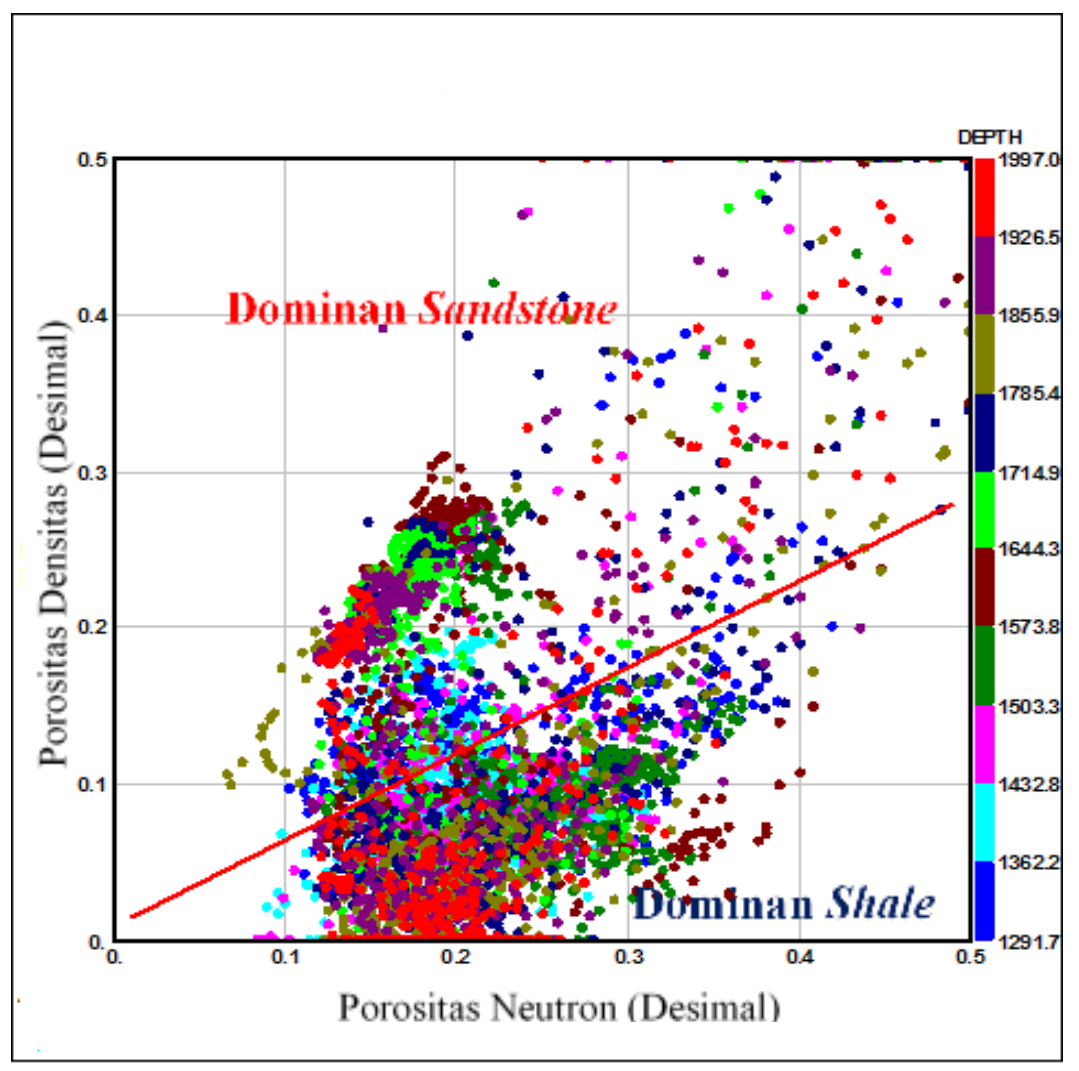

Gambar 6. Plot silang porositas neutron dan porositas densitas untuk memisahkan lapisan sandstone dengan lapisan shale pada sumur JML-1.

Lapisan shale yang mengandung fluida akan memiliki nilai densitas yang kecil dan log gamma ray yang tinggi. Litologi yang mengandung hidrokarbon akan memiliki porositas neutron yang lebih kecil dari lapisan tanpa hidrokarbon. Definisi tersebut berlaku untuk lapisan shale yang mengandung konten hidrokarbon (gambar 7). 


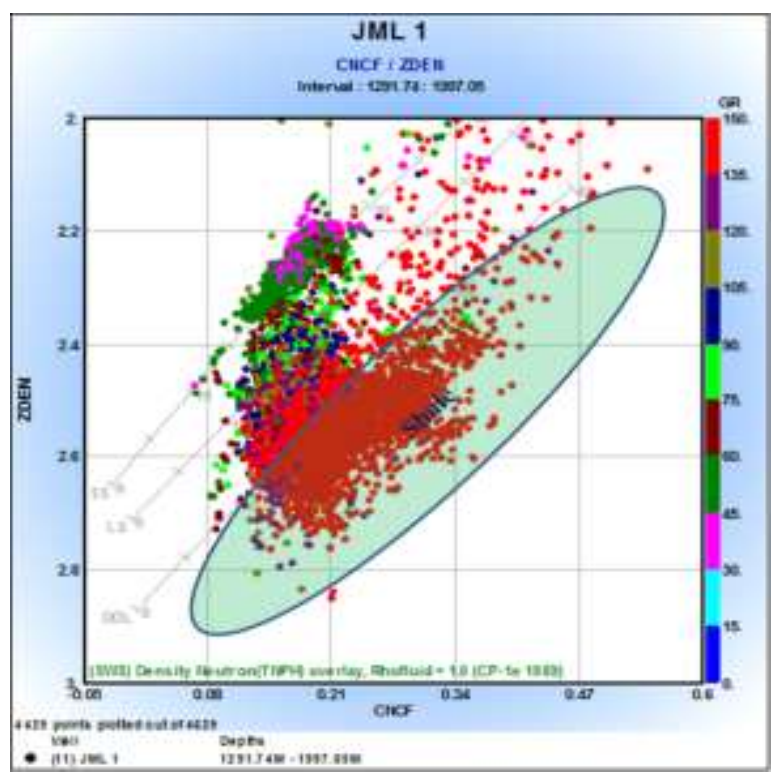

Gambar 7. Plot silang antara log neutron dan log densitas

Berdasarkan dari analisis laboratorium geokimia, kekayaan karbon organik (TOC) pada daerah penelitian sekitar $0.72-6.12$ $\%$ wt. Namun data tersebut hanya terukur pada interval kedalaman tertentu, sehingga untuk mengetahui penyebaran TOC secara vertikal dilakukan estimasi log kekayaan dengan menggunakan metode $\Delta \log R$ (Metode Passey) (gambar 8).

Dari hasil plot silang TOC lab. terhadap TOC model dengan menggunakan metode Passey (gambar 9) didapatkan nilai regresi linier sebesar 0,7205 yaitu probability sebesar $72,05 \%$. Analisis pemodelan TOC yang diberikan dengan hasil regresi antara TOC model dengan TOC lab yang kurang bagus, dikarenakan parameter yang digunakan dalam pemodelan TOC metode Passey diharuskan memasukkan nilai baseline zona shale. Selain itu, diakibatkan karena terjadinya shifting antara dari data kellybushing $(\mathrm{kb})$. Passey mengasumsikan bahwa zona shale yang kaya akan bahan organik maka respons resistivitas batuan akan tinggi dan diikuti oleh penurunan kecepatan gelombang sonik kompresional.

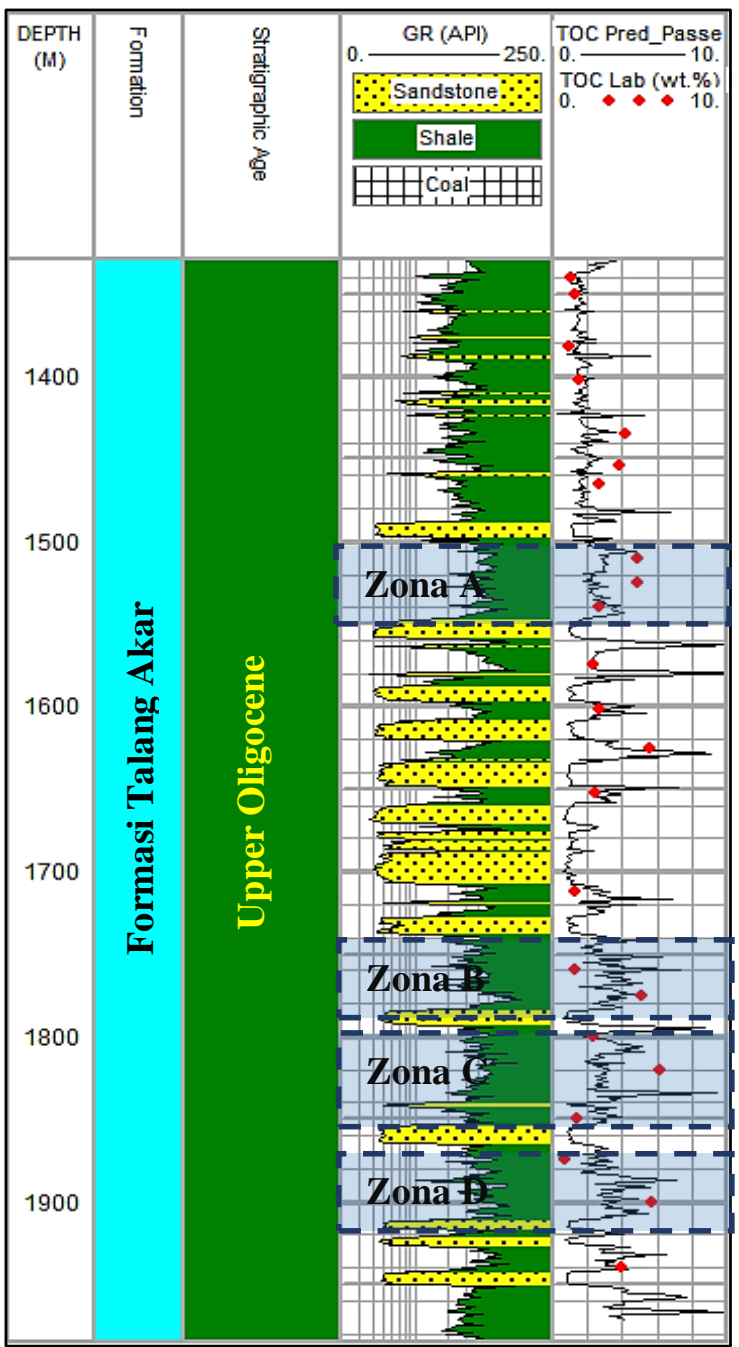

Gambar 8. Pemodelan TOC menggunakan metode Passey. 


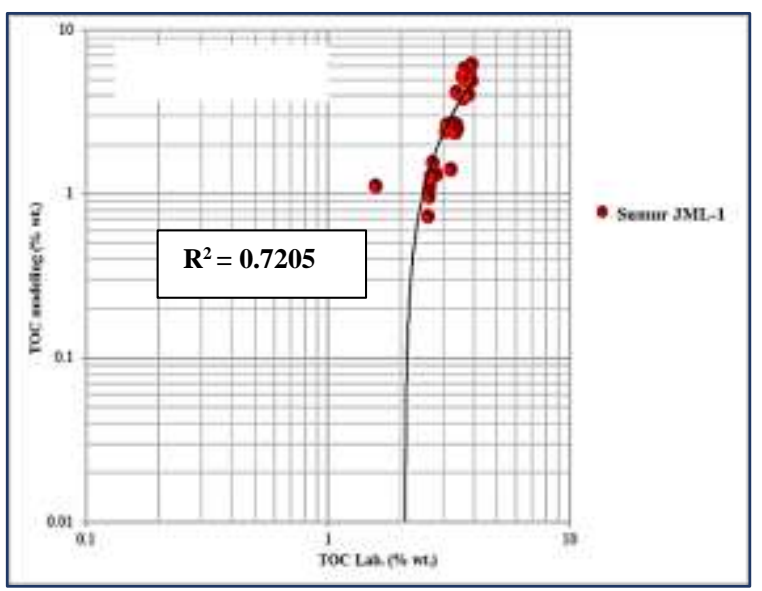

Gambar 9. Hasil korelasi antara TOC Lab. dan TOC pemodelan.

\section{Kesimpulan}

Berdasarkan penelitian tersebut terdapat 4 (empat) yang termasuk zona potensi yaitu:

- Zona A pada kedalaman 1497-1546 m;

- Zona B pada kedalaman 1738-1784 m;

- Zona C pada kedalaman 1792-1852 m;

- Zona D pada kedalaman 1863-1910 m.

Nilai kandungan material organik di Formasi Talang Akar berkisar antara $0.72-$ $6.12 \%$ wt. yang mengindikasikan bahwa formasi tersebut sebagai batuan induk antara berpotensi rendah sampai sangat baik untuk menghasilkan hidrokarbon.

\section{Daftar Pustaka}

Aly., et al. 2003. Resistivity, Radioactivity, and Porosity as tools to evaluate the organic content of Abu Roash "F" and "G" Members, North Western Desert, Egypt. EGS Journal, vol.1, No.1, 129-137.

Argakoesoemah, R.M.I., dan Kamal, Asril. 2004. Ancient Talang Akar Deepwater Sediments in South Sumatra Basin: A New Exploration Play. Proceedings Deepwater and Frontier Exploration in Asia and Australia Symposium:
Indonesian Petroleum Association, DFE04-OR-009, p. 1 - 17.

Badan Geologi. 2011. Map of Distribution and Potential of Shale Oil and Gas Bearing Formation of Indonesia. Quaternary. Neogene. Paleogene.

Davis, J. L.. 1992. Depositional System, An Introduction to Sedimentology and Stratigraphy. $2^{\text {nd }}$ ed. Prentice Hall, Englewood Cliffs, New Jersey, 604p.

De Coster, G. L. 1974. The Geology of the Central and South Sumatera Basins. Proceedings $3^{\text {rd }}$ Annual Convention, Indonesian Petroleum Association, Jakarta, Indonesia, Juni, 77-110.

Heidrick, T. L., and Aulia, K. 1993. A Structural and Tectonic Model of The Coastal Plains Block, Central Sumatra Basin, Indonesia. Proceedings Indonesian Petroleum Association. 22 $2^{\text {nd }} \quad$ Annual Convention, IPA 93-1.1-179 Jakarta.

Katahara, Keith. 2008. What is Shale to a Petrophysicist?. The Leading Edge June 2008, 738-741.

Passey, Q. R., S. Creaney, J. B. Kulla, F. J. Moretti, and J. D. Stroud. 1990. A practical model for organic richness from porosity and resistivity logs. AAPG Bulletin, 74, .1777-1794.

Pulunggono, A., Haryo, S. Agus, and Kosuma, C. G. 1992. Pre-Tertiary and Tertiary fault systems as a framework of the South Sumatra Basin; a study of sar-maps. Proceedings Indonesian Petroleum Association Twenty First Annual Convention, October, 1992, p. 339360. 